


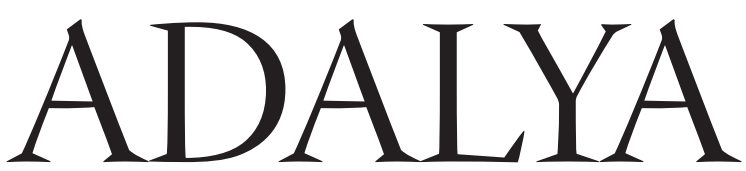

The Annual of the Koç University Suna \& İnan Kıraç Research Center for Mediterranean Civilizations

(OFFPRINT) 


\section{ADALYA}

The Annual of the Koç University Suna \& İnan Kıraç Research Center for Mediterranean Civilizations (AKMED)

Mode of publication

Adalya, a peer reviewed publication, is indexed in the A\&HCI

(Arts \& Humanities Citation Index) and CC/A\&H (Current Contents / Arts \& Humanities)

Adalya is also indexed in the Social Sciences and Humanities Database of TÜBİTAK/ULAKBIM TR index and EBSCO.

Publisher certificate number

Worldwide periodical

18318

ISSN 1301-2746

Publisher management

Koç University

Rumelifeneri Yolu, 34450 Sariyer / İstanbul

Publisher Umran Savaș İnan, President, on behalf of Koç University

Editor-in-chief Oğuz Tekin

Editors Tarkan Kahya and Arif Yacı

English copyediting Mark Wilson

Editorial Advisory Board (Members serve for a period of five years)

Prof. Dr. Mustafa Adak, Akdeniz University (2018-2022)

Prof. Dr. Engin Akyürek, Koç University (2018-2022)

Prof. Dr. Nicholas D. Cahill, University of Wisconsin-Madison (2018-2022)

Prof. Dr. Edhem Eldem, Boğaziçi University / Collège de France (2018-2022)

Prof. Dr. Mehmet Özdoğan, Emeritus, Istanbul University (2016-2020)

Prof. Dr. C. Brian Rose, University of Pennsylvania (2018-2022)

Prof. Dr. Charlotte Roueché, Emerita, King's College London (2019-2023)

Prof. Dr. Christof Schuler, DAI München (2017-2021)

Prof. Dr. R. R. R. Smith, University of Oxford (2016-2020)

(c) Koç University AKMED, 2020

Production Zero Production Ltd.

Abdullah Sok. No. 17 Taksim 34433 İstanbul

Tel: +90 (212) 2447521 • Fax: +90 (212) 2443209

info@zerobooksonline.com; www.zerobooksonline.com

Printing Fotokitap Fotoğraf Ürünleri Paz. ve Tic. Ltd. Şti.

Oruç Reis Mah. Tekstilkent B-5 Blok No: 10-AH111

Esenler - İstanbul / Turkey

Certificate number: 47448

Mailing address

Barbaros Mah. Kocatepe Sok. No. 22

Kaleiçi 07100 Antalya - TURKEY

Tel: +90 (242) 24342 74 • Fax: +90 (242) 2438013

https://akmed.ku.edu.tr

E-mail address $\quad$ adalya@ku.edu.tr 


\section{Contents}

Burçin Erdoğu

Capturing the Seen and Unseen in the Beldibi Rock Art .. 1

Özlem Çevik - Murat Dirican - Aydın Ulubey - Osman Vuruşkan

The Galena Objects from Neolithic Ulucak: The Earliest Metallic Finds in Western Turkey 7

Abdullah Hacar - K. Aslıhan Yener

Anatolian Pot Marks in the 3rd Millennium BC: Signage, Early State Formation, and

Organization of Production 25

A. Tuba Ökse

Reflection on the Sunrise Positions in Early and Middle Bronze Age Extramural

Cemeteries in Anatolia 59

Sevgül Çilingir Cesur

The Timing of Ritual Performance in Hittite Texts: The "Morning" Rites 87

Dries Daems

Reassessing the Origin of Polis in Lycia and Southwest Anatolia 111

Fatma Şahin - Erkan Alkaç

Banded Bowls from Tepebağ Höyük (Cilicia Pedias)

Özgün Kasar - Kaan İren

Leaded Bronze Arrowheads at Daskyleion 175

Hazar Kaba

An Elite Tomb from Soloi: New Evidence for the Funerary Archaeology of Cyprus

Erkan Alkaç - Ulus Tepebaş

The Gem Stamp on the Handle of a Mushroom-rimmed Amphora from Knidos:

An Assessment of the Centauromachy in Terms of Stamps and Iconography

Hüseyin Sami Öztürk - Ögül Emre Öncü

Olympos in Lycia: A Novel Assessment of its History and Localization in Light of Recent

Archaeological and Epigraphical Research

Nihal Tüner Önen

Two New Inscriptions from the Claudian Period at Perge 277

Handegül Canlı

A Unique Roman Folding Knife Handle with Eagle Ornament from Philadelphia in Cilicia 289 
Şenkal Kileci - Birol Can

A New Honorific Inscription from Blaundos: Tiberius Claudius Lucius, the Priest of

Dionysos Kathegemon

Ahmet Tolga Tek - Hacer Sancaktar

A Numismatic Riddle from Arykanda: The God of the Water Spring .

Mark Wilson

The Discovery of a Menorah in Attalia (Kaleiçi, Antalya) and its Significance for

Jewish Communities in Pamphylia

Özgü Çömezoğlu Uzbek

A North African Plate Unearthed in the Andriake Excavations

Philip Bes

Early Byzantine Pottery from Limyra's West and East Gate Excavations

Nilgün Elam

Ecclesiastical Personages of Side ( $\Sigma i \delta \eta$ ) of Pamphylia according to Literary and Sphragistic Data

Ömür Bakırer

Window Glass from the Excavations in the Seljuk Palace at Alanya

Mahmut Demir - Terrance Michael Patrick Duggan - Erkan Kurul

Observations and Assessments of Some Epigraphic Graffiti Found on Entrances in

Kaleiçi/Antalya

Ayşe Ozil

A Traveller in One's Homeland: Local Interest in Archaeology and Travel Writing in the

Ottoman Greek World in 19th Century Anatolia

Alex Rodriguez Suarez

Two Church Bells from Antalya: Traces of the Religious Soundscape of the Late Ottoman Period 517 


\title{
The Gem Stamp on the Handle of a Mushroom-rimmed Amphora from Knidos: An Assessment of the Centauromachy in Terms of Stamps and Iconography
}

ERKAN ALKAÇ - ULUS TEPEBAŞ*

\begin{abstract}
In 1973 a fragment of a stamped amphora with a mushroom-shaped rim was found during archaeological excavations at the "West Harbour Byzantine Church E" in Knidos. The gem-shaped stamp on the handle of this amphora features a mythological scene of a battle between a Centaur and a Lapith. The figure on the right-hand side of the scene on the gem stamp is the Lapith while the half human-half horse figure on the left is the Centaur. The heads and faces of both figures have eroded. Nevertheless, it is possible to provide information about their compositions on the scene. The torso of the Lapith figure on the right is depicted frontally, while the left leg is depicted from the side and right leg from the front. Mushroom-rimmed amphorae were produced at numerous centers across the southern Aegean region including Samos, Rhodes, Knidos, Kos, Halikarnassos, Peparethos,
\end{abstract}

Öz

1973 y1lında Knidos'da "Bat1 Liman1 Bizans E Kilisesi” kazı çalışmalarında mantar formlu ağız kenarına sahip mühürlü bir amphora parçası bulunmuştur. Bu amphoranın kulpunda bulunan gemme şeklindeki mühürde, Kentaur ile Lapith mücadelesini konu alan mitolojik bir sahne işlenmiştir. Gemme mühürdeki sahnenin sağındaki figür Lapith solundaki yarı insan yar1 at betimli figür ise Kentaur'dur. Her iki figürün başları ve yüzleri aşınmıştır. Buna rağmen sahnedeki kompozisyonlarına dair bilgi vermek mümkündür. Sağdaki Lapith figürünün gövdesinin üst bölümü cepheden, sol bacağ1 profilden ve sağ bacağı cepheden verilmiştir. Mantar ağız formuna sahip amphoralar Güney Ege Bölgesi'nde Samos, Rhodos, Knidos, Kos, Halikarnassos, Peparethos, Klazomenai ve Phokaia gibi birçok merkezde üretilmiştir. Makaleye konu olan mantar ağızlı amphora, Ege Bölgesi'nde ya da bu coğrafyaya yakın

* Assoc. Prof. Dr. Erkan Alkaç, Mersin Üniversitesi, Fen-Edebiyat Fakültesi, Klasik Arkeoloji Anabilim Dalı, Arkeoloji Bölümü, Çiftlikköy Kampüsü, 33343 Mersin. Türkiye. E-mail: ealkac77@gmail.com; https://orcid. org/0000-0001-9436-2501

Dr. Ulus Tepebaş, Mersin Üniversitesi, Fen-Edebiyat Fakültesi, Klasik Arkeoloji Anabilim Dalı, Arkeoloji Bölümü, Çiftlikköy Kampüsü, 33343 Mersin. Türkiye. E-mail: ultepebas@gmail.com ; https://orcid.org/0000-0003-4182-9969

This study was conducted with the Decision of the Council of Ministers with no. 2013/5387 on the date 30.09.2013 and was done with the permission of the Knidos Excavation Directorship in accordance with the scope of Knidos Excavation and Research carried out on behalf of Selçuk University and the Ministry of Culture and Tourism. We are grateful to the Knidos excavation director, Prof. Dr. Ertekin M. Doksanalt1, for issuing the necessary permissions for us to study this fragment and for sharing his ideas on it. We would also like to thank Prof. Dr. Gonca Cankardeș Şenol and Assoc. Prof. Dr. Erkan Dündar for sharing their ideas on the amphora's shape and stamp, and Songül Sözel (MA) for drawing the amphora. The study of the Centauromachy iconography on the stamp was carried out by Dr. Ulus Tepebas in 2019 in the AKMED library as an AKMED scholarship holder while participating in the Monetary History and Numismatics Summer School. We would like to thank the AKMED authorities for this opportunity. 
Klazomenai and Phokaia. The mushroomrimmed amphora, the subject of this article, must have been produced in the Aegean region or nearby. The production of mushroomrimmed amphorae is regarded as a reflection of a regional perception. Although these amphorae generally abide by the same form, some differences in shape can be observed. Stamps are rarely found on mushroom-rimmed amphorae. The stamps on this shape often consist of monograms and ligatures, not mythological scenes like that of the Lapith and Centaur. The depiction of this battle on the Knidos find is a unique example. This mushroom-rimmed amphora should be dated to the second half of the 4th century BCE based on similar examples in terms of form.

Keywords: Knidos, mushroom-rimmed amphora, gem amphora stamp, Lapith, Centaur bir noktada üretilmiş olmalıdır. Mantar ağızlı amphoraların üretimi bölgesel bir anlayışın yansıması olarak değerlendirilmektedir. Bu amphoralar, genel olarak aynı formda üretilmiş olsalar da, bazı form farklılıkları da gözlenmektedir. Mantar ağılı amphoralarda nadiren mühürler görülmektedir. Bu formdaki mühürler, monogramlardan veya ligatürlerden oluşmaktadir ki Lapith ve Kentaur gibi mitolojik sahneler bulunmamaktadir. Knidos buluntusu üzerinde bu mücadelenin tasvir edilmesi, ünik bir örneği oluşturmaktadır. Bu mantar ağızlı amphora, form açısından yakın benzerlerinden dolayı, MÖ 4. yüzyılın ikinci yarısına tarihlenmelidir.

Anahtar Kelimeler: Knidos, mantar ağılı amphora, gemme amphora mühürü, Lapith ve Kentauros

\section{Introduction}

In 1973 a fragment of a stamped amphora with a mushroom-shaped rim was found during archaeological excavations at the "West Harbour Byzantine Church E" in Knidos' (figs. 1-2, cat. no. 1). The work is unique because the gem-shaped stamp on the handle of the amphora features a mythological scene of a battle between a Centaur and Lapith (fig. 3).

The stamps retrieved at the Knidos excavations between 1968 and 1977 were stored in the depot of the Bodrum Museum for many years. In 2018 these stamps were brought to the excavation house under the initiative of excavation director, Ertekin M. Doksanalt1. During the studies on amphora stamps carried out at Knidos, this piece stood out in terms of shape, ${ }^{2}$ stamping and iconography. The aim of this article is to date the stamp, provide a suggestion on the origin of the amphora, determine its significance in terms of amphora stamping, and evaluate the iconography on the stamp.

Only one fragment comprising the rim, neck and handle of this mushroom-rimmed amphora from Knidos has survived (figs. 1-2). This amphora features a mushroom-shaped/out-turned rim with a triangular cross-section, a cylindrical neck, and an oval-sectioned handle which rises slightly before bending down towards the neck with a narrow curve. There is a projection underneath the exterior part of the triangular-sectioned rim, close to the neck. The clay composition of both the cross-section and the surface of the amphora includes a high concentration of lime, moderate amounts of sand, a small amount of chamotte, and a few stone particles, quartz and silver mica inclusions. The clay has a hard texture. Although darkening caused by firing can be seen both on the surface and cross-section, a red clay structure can be observed in the cross-section. Darkening on the amphora surface and section is caused by reduction firing (without extra air intake).

1 Doksanalt1 et al. 2019, 45-64; 2018, 5.

2 Alkaç 2019. 


\section{Mushroom-Rimmed Amphora Production in Western Anatolia and the Aegean Islands}

Mushroom-rimmed amphorae found at the Solokha kurgan excavations were first introduced by Zeest as the "Solokha I Amphorae" in seven different typologies. ${ }^{3}$ This amphora type usually features a mushroom-shaped rim, a short cylindrical neck that widens towards the shoulders, short handles with an oval cross-section that start immediately under the rim and extend down towards the shoulder, a broad-shouldered ovoidal body, and a knob-like toe which is hollow underneath. ${ }^{4}$

The earliest examples of mushroom-rimmed amphorae were found inside a deposit dated to the third quarter of the 5th century BCE at the Athenian Agora. ${ }^{5}$ Mushroom-rimmed amphorae were quite common between the 5th and 3rd centuries BCE. Although there is no confirmation on their original place of production, this commercial form was quite popular as of the 4 th century BCE. ${ }^{6}$ This type of rim can also be observed on some amphora produced in the 2nd century BCE. ${ }^{7}$

The first examples of mushroom-rimmed amphora on the island of Kos were produced at the end of the 5th century BCE. Meropis is known as the first workshop to produce mushroom-rimmed amphorae on the island. ${ }^{8}$ Another workshop which produced this type of amphora on the island was Kardamaina. ${ }^{9}$ Mushroom-rimmed amphora produced on Kos have monofide and bifides handles. ${ }^{10}$

Samos is known as a production center for mushroom-rimmed amphorae; however, there is no proof that this form was actually produced on the island. It is argued that mushroomrimmed amphorae were produced on the island during the 4th century BCE because this form featured the stamp with a lion's head, Pan, Herakles, Eros and Siren, which is unique to Samos. ${ }^{11}$

Archaeological data obtained from surveys have revealed that mushroom-rimmed amphorae were also produced on the island of Peparethos. This group of amphorae classified as "Peparethos II" is dated to the second quarter and mid-4th century BCE. Mushroom-rimmed amphorae from Peparethos are similar to examples of Solokha I in terms of dimension and form. The clays of examples from Peparethos are yellow and orange-red. Grooves can be observed on the base and neck of some mushroom-rimmed amphorae from this island. Some of the stamps used on the amphorae bear letters in relief or englyphic letters $(\Delta, \mathrm{E}, \mathrm{M}, \Phi, \mathrm{A} \Theta){ }^{12}$

Fragments of mushroom-rimmed amphorae, reminiscent of the Solokha I type, have been found in a pottery workshop at Klazomenai dated to the third quarter of the 4th century BCE.

\footnotetext{
3 Zeest 1960, 150-52, pl. 14-16.

4 Dündar 2017, 68.

5 Lawall 1995, 218.

6 Özbay 2019, 83.

7 Cankardeş-Şenol 2001, 106-7, nos. 9-11, figs. 9-11.

8 Papuci-Wladyka 1997, 48-49, fig. 1.1.

9 Georgopoulou 2001.

10 Kantzia 1994, 332-42, figs. 5-10, pls. 255-56, 260.

11 Grace 1971, 67, pl. 15, no. 11; 91-92, nos. 57-61, pls. 14.

12 Doulgéri-Intzessiloglou and Garlan 1990, 384, 386.
} 
This indicates that Klazomenai was a production center for this shape. ${ }^{13}$ It is likely that the mushroom-rimmed form was produced in Klazomenai even before this date because numerous mushroom-rimmed amphora fragments dated to the end of the 5th century BCE were discovered at Klazomenai's HBT Sector. This suggests that the form was produced at the workshops of Klazomenai since the form first emerged. ${ }^{14}$

Similar to all the centers across the Aegean, producers at Knidos had started making mushroom-rimmed, ovoidal-bodied and hollow and out-turned, high-based amphorae around the mid-4th century BCE. ${ }^{15}$ The production of this form increased at Knidos parallel to the growing wine exports of the last quarter of the 4 th century BCE. ${ }^{16}$ Reşadiye has been identified as the center of mushroom-rimmed amphora production on the Datça Peninsula. ${ }^{17}$ Archaeological excavations carried out at the production areas here have revealed pottery dumps for these types containing examples of surplus mushroom-rimmed amphorae. The amphora producers of Knidos created various types of mushroom-rimmed amphorae before developing a characteristic form of their own. Şenol categorizes these amphorae into three groups based on their rim forms. ${ }^{18}$ Some mushroom-rimmed amphorae dated to the 4th century BCE, retrieved near Kiliseyanı Mevki in the village of Hızırşah and associated with this workshop, carry stamps consisting of the monograms/abbreviations $\mathrm{AP}\left(, \Sigma \mathrm{I}\left(\right.\right.$ and $\Pi \mathrm{A \Theta}\left(.{ }^{19}\right.$ The majority of stamps with ship-prow symbols dated to ca. 325 - ca. 280 BCE were stamped on mushroom-rimmed amphorae. ${ }^{20}$ Dating from the middle to the third quarter of the 4th century BCE, the earliest known example of mushroom-rimmed amphora produced in Knidos were found at the Burgaz excavations. ${ }^{21}$

It is believed that mushroom-rimmed amphorae were produced in Rhodes in the second half of the 4 th century BCE. ${ }^{22}$ The oval stamps on the handles of the mushroom-rimmed amphorae from Patara bear an amphora symbol as well as the letters $\mathrm{A}$ and $\mathrm{O}$ or $\mathrm{A}$ and $\Theta$. The form of the amphora on the stamp is striking for its resemblance to actual examples with mushroom-shaped rims. These stamps are dated to the end of the 4th century BCE. ${ }^{23}$

Research carried out around Bybassos has proven that amphorae with cylindrical necks and mushroom-shaped rims were produced at the Rhodian Peraea in the Early Hellenistic Period. ${ }^{24}$ It has been determined that band-rimmed and mushroom-rimmed amphorae were produced at a workshop identified at the Çamlı-Çınar region in the Peraea. The mushroom-rimmed amphorae produced at the Çaml-Çınar workshop have been dated to the late 4th - early 3rd century BCE. ${ }^{25}$

13 Doğer 1986, 470, fig. 18.

14 Özbay 2019, 83; Hasdağlı 2012, 138.

15 Şenol 2009, 126.

16 Şenol and Aşkın 2007, 265.

17 Tuna et al. 1987, 48 .

18 Şenol 1995, 1-2.

19 Tuna 1990, 358-59, figs. 13-14; For the Knidian Mushroom-rimmed Amphora stamps, see also Jefremow $2013,410$.

20 Cankardeş-Şenol 2015, 170.

21 Sakarya 2016, 185, no. 45.

22 Grace 1971, 67.

23 Dündar 2017, 84-85, rh. 1-1.

24 Senol 2015b, 193-95.

25 Doğer and Şenol 1996, 64-65. 
Research carried out at Ampelas located in the northeast part of the island of Paros confirm that amphorae with mushroom-shaped rims were produced during the Hellenistic Period. The vases produced at this workshop had mushroom-rims with an outward angle, and the knobshaped base was hollow. ${ }^{26}$

Amphorae that have stamps with the name Nikandros on their handles have been discovered at Delos. ${ }^{27}$ These amphorae have sagging, small mushroom-shaped rims, long cylindrical necks, vertical handles which begin underneath the rim and attach to the slanting shoulders, a triangular body, and hollow knob-shaped bases. ${ }^{28}$ The form characteristics of these amphorae, classified as the Nikandros Group, appear to have been influenced by South Aegean amphorae with mushroom-shaped rims. ${ }^{29}$ Recent studies have confirmed that this amphora type was produced around Ephesus and Metropolis in Western Anatolia. ${ }^{30}$ This amphora group has clay colors ranging from pale grey, pale brown to yellow-red and inclusions of lime, mica and chamotte. ${ }^{31}$ Nikandros Group amphorae are generally dated to the 3rd and 2nd centuries BCE. ${ }^{32}$

Despite the various clay compositions, this amphora type bears similarities in form which features a triangular-shaped rim with an outward angle and knob-shaped, hollow base. This amphora type was produced in several centers across the southern Aegean including Rhodes, Knidos, Kos, Paros, Peparethos, Halikarnassos, Phokaia and Klazomenai. Amphorae with mushroom-shaped rims were replaced by the canonical amphorae of the cities towards the end of the third quarter of the $3^{\text {rd }}$ century BCE. ${ }^{33}$ There are hypotheses which advocate the existence of production centers of mushroom-rimmed amphorae other than the ones mentioned above. Although these amphorae have common features in terms of form, it is difficult to establish a clear account of the shape development as they were produced in multiple centers. ${ }^{34}$ Amphorae with mushroom-shaped rims have issues on their chronology and workshop, so the production is regarded to reflect a regional perspective and offer an understanding on the development of "koine". Minor differences observed on the rim of the basic custom form could be due to them being produced in different workshops/centers or typological and chronological development, but it could also be due to the potter's craftsmanship during the fast production. Detailed studies and analyses on examples retrieved at production centers could help quicken the process of resolving issues concerning this amphora type. ${ }^{35}$

\section{An Assessment of the Centaur-Lapith Battle on the Gem Stamp in Terms of Iconography and Typology}

This section will initially provide information on the composition and chronological iconography of the figures featured on the stamp. Then it will go on to provide a detailed account of

\footnotetext{
26 Empereur and Picon 1986, 504-5, fig. 9 a-c.

27 Grace and Savvatianou-Petropoulakou 1970, 365

28 Cankardeş-Şenol 2006, 167, fig. 227.

29 Şenol 2015b, 245.

30 Cankardeş-Şenol 2006, 165.

31 Cankardeş-Şenol 2010, 127.

32 Lawall 2004a, 177-88.

33 Şenol and Aşkın 2007, 265.

34 Coşkun and Çevirici-Coşkun 2017, 238.

35 Dündar 2017, 68, 72.
} 
the use of this iconography in the geographical area where the stamp was found and why such iconography was found on a stamp.

There are two figures in relief standing opposite each other inside an elliptic area. The figure on the left is the Lapith while the half-human, half-horse figure on the right is the Centaur (fig. 3). The heads and faces of both figures have eroded. Nevertheless, it is possible to provide information about their compositions on the scene. The torso of the Lapith figure on the left is depicted frontally whereas the left leg is in profile and the right leg is frontal. The Lapith has his right arm pulled back and slightly bent from the elbow as if to prepare to attack; his left arm is extended towards the head of the figure opposite. The garment hanging from underneath both arms of the figure is thought to be a chlamys. The left leg of the Lapith is bent from the knee, tense under the weight with his left foot stepping on a horizontal area made to look like a surface. A step back, his right leg is straight and tense, fixed firmly. The torso of the Centaur on the right is from a semi-profile view while the horse-shaped lower body is shown in profile. The left arm is bent from the elbow in a right angle towards the head; he holds a branch with this hand. ${ }^{36}$ The right arm of the Centaur is not visible in the scene. His front legs are eroded, but he maintains a position poised to attack his opponent, reared up like a horse. Straining under the full weight of his body, the hind legs are slightly bent from the knees. His "S" shaped tail, which thins out towards the tip, is well preserved. The figures featured in the scene as the Centaur and Lapith compose a scene from the Centauromachy, an account of the conflict and battle between the Centaurs and Lapiths, a popular story in antiquity.

In mythology, the half-horse, half-human Centaurs of double form ${ }^{37}$ are generally portrayed as instinctive, wild, rude, barbaric creatures with a weakness for women and wine. ${ }^{38}$ These mentioned characteristics are based on Eurytion's behavior as portrayed in the well-known Centauromachy myth. Eurytion was invited to Peirithoos' wedding, but after too much wine, he caused trouble for the bride and the guests. Here, Eurytion became the instigator of a war between the Centaurs and the Lapiths. It also marked the beginning of extended hostility and conflict between humans and the Centaurs. ${ }^{39}$ The following is how the mythological story between the two creatures transpired: "Lapith Leader Peirithoos of Thessaly was to marry Hippodameia (=Laodameia). Among the invitees were Centaurs who were hosted inside a cave close to the wedding house. Intoxicated by wine, the Centaurs became insolent (bybris). While welcoming all the guests, the bride visited the Centaurs as well. However, the Centaur Eurytion attempted to abduct the bride, sparking a war. At first, the Lapiths outflank their opponents. However, they lose several warriors during the battle, but ultimately the Centaurs were defeated and ostracized from Thessaly". ${ }^{40}$

Centaur representations are frequently found on almost every kind of archaeological material and conducting numerous functions. ${ }^{41}$ Centaur representations are of Eastern origin. Their earliest examples have been found on prism stamps imported from Babylon (ca. 2500-2000 BCE) which were retrieved in Crete. Although their origin is Babylon, these examples carry a Hittite influence. On the other hand, figures of creatures resembling Centaurs were used as

36 Beazley 1963.

37 Apollodoros 1.2.

38 Hölscher 2000.

39 Homer Il. 2, 740; Homer Odys. 21, 295 and 303.

40 Roscher 1890-1894, 1032.

41 For these early examples also, see Padgett et al. 2003. 
border stones by the Kassites who lived in East Babylon. ${ }^{42}$ Early examples of Centaur representations have been discovered in Cyprus due its geographical location. ${ }^{43}$

The oldest known example from the ancient Greeks was retrieved as a tomb find at Lefkandi, Euboea, and dated to the 10th century BCE. ${ }^{44}$ During the Archaic Period Centauromachy scenes were depicted in the painted metopae ${ }^{45}$ of the Temple of Apollo Lykeios in Thermos in the 6th century BCE and the Athena Temple at Assos ${ }^{46}$ in the mid-6th century BCE.

During the Classical Period, Greek victories against the Persians were frequently referred to in architecture based on the topic of the Centauromachy. ${ }^{47}$ In chronological order, the following buildings include such depictions on the wall paintings of the Theseion at Athens (470-465 BCE),${ }^{48}$ the west pediment of the Temple of Zeus at Olympia (464-457 BCE) ${ }^{49}$ the south metopae of the Parthenon (ca. $450 \mathrm{BCE}$ ) ${ }^{50}$ the west friezes of the Temple of Hephaistos at Athens (460-449 BCE), ${ }^{51}$ the friezes of the Temple of Poseidon at Cape Sounion (444-440 BCE), ${ }^{52}$ and the interior friezes of the Temple of Apollo Epikourios at Bassai (450-400 BCE). ${ }^{53}$ In the 4th century BCE, the Battle of the Centaur and Lapith appears on the 380-360 BCE friezes of the Temple of Athena Pronaia. ${ }^{54}$

During the 4th century BCE, the subject of the Centauromachy frequently appears on architecture in cities across the Lycia region which was known to have close ties with Knidos. The first was discovered at the settlement of Trysa (Antalya/Demre/Gölbaş1) in central Lycia. A Centauromachy scene was depicted on the friezes of the south exterior wall and north interior wall of the Heroon. ${ }^{55}$ The composition of the Centaur and Lapith scene, which begins immediately to the left of the entrance, is particularly similar to the depiction on the stamp. These similarities are seen at the moment where the Lapith extends his right arm towards the Centaur and the Centaur retracts his left arm. ${ }^{56}$ Both figures portray a similar offensive against each other. The only difference is that, in the relief at Trysa, the Lapith swings the blade in his right hand and the Lapith retracts both arms. Considering dimensional differences between the stamp and the relief friezes, it is normal to see such adaptations and less stylistic detailing, especially regarding clothing. Such variations are inevitable because there are dimensional differences as well as the stamp being an impression and the relief being a carving. Similarities with the Trysa relief are the rock underneath the front legs of the Centaur and his rearing movement

42 Although some of these examples have been identified as Sagittarius, it is stressed in the relevant sources that they are not related to the zodiac or Sagittarius. For examples of early Centaur depictions, see Baur 1912, 2.

43 Karageorghis 1966, 164-69.

44 Desborough et al. 1970.

45 Schiffler 1976, 163-64.

46 Ridgway 1999, 151.

47 Tarbell 1920, 227.

48 Podlecki 1971.

49 Ridgway 1999, 17. For more detailed information on the dating of the sculpture from the temple, see PatayHorváth 2015, 9.

50 Jenkins 2006, 74. For more detailed information on the dating of the sculpture from the temple, see Jenkins 2007.

51 Morgan 1962, 222-23; Barringer 2009, 121-25.

52 Delivorrias 1969; Dinsmoor 1975, 181-82; Felten and Hoffelner 1987.

53 Jenkins 2006, 143-45.

54 Ridgway 1999, 155.

55 Childs 1978, 13-14.

56 Ridgway 1999, 155. Benndorf and Niemann 1889, tables XXV B3, XXVII-XXVIII. Südwand Aussen B3. For information on the discussions on typology and similarities with the Trysa Gölbaşı Heroon, see Childs 1978. 
with his torso depicted from a semi-profile angle. The Lapith folds his left leg from the knee and attacks with his right arm. Considering the close proximity of Knidos and Trysa as well as the similarities in composition, the scene on the stamp was inspired by the Trysa Gölbaş1 Heroon $^{57}$ in the Late Classical Period.

The Centaur depiction on the stamp can be evaluated from a typological perspective (fig. 3). The striking aspect of early examples of Centaurs from ancient Greece is their physical characteristics with the upper body of a human and the lower body of a horse. P.V.C. Baur categorizes these early Centaur examples in three groups: The "A Group" examples have the front legs of a horse, "B Group" examples have human feet on the front legs, and "C Group" examples have hooves instead of feet. These details are unclear on the stamp. Nevertheless, the Centaur typology developed in the 4th century BCE. Problems concerning the merging of the human and horse bodies in particular were resolved on the metopae of the Parthenon. And the typological application here later became a template for future depictions. Moreover, the stamp with the Centauromachy scene retrieved at Knidos adopts Row VII of the south metope at the Parthenon ${ }^{58}$ in terms of typology and composition and looks quite similar. Other heroons featuring the Centauromachy scene during the Hellenistic Period appear between the 3rd and 1st centuries BCE. These include the Belevi Mausoleum, ${ }^{59}$ the Ptolemaion at Limyra, ${ }^{60}$ and a frieze retrieved at Mylasa. ${ }^{61}$ It has been suggested that Hellenistic examples of Centauromachy scenes in Asia Minor were influenced by the Mausoleum of Halikarnassos during the Hellenistic Period. ${ }^{62}$

\section{Conclusion}

A comparison of similar amphora examples was made to determine the date of the mushroom-rimmed amphora recovered at the West Harbour Byzantine Church E in Knidos. The mushroom-rimmed amphora recovered at the Burgaz excavations on the Datça Peninsula and dated to between the middle and third quarter of the 4th century BCE bears resemblance in terms of form to this fragment - the subject of this article. The similar amphora from Burgaz has been classified as a "Mushroom-rimmed amphora from Knidos". ${ }^{63}$ A very similar version of the mushroom-rimmed amphora from Knidos, which is classified as "Knidos Variant 1-C", was recovered at Geroevkai and dated to the third quarter of the 4th century BCE. ${ }^{64}$ The example from the Preserve Museum amphorae collection, classified as "Knidos Variant 1-C" and dated to the third quarter of the 4th century BCE, is similar to the Knidos find in terms of form. However, unlike the Knidos find, the projection on the exterior of the mushroom-shaped rim of the Preserve example is located at the point where the rim joins the neck. ${ }^{65} \mathrm{~A}$ similar version of the rim-neck and handle fragment recovered at Knidos from Klazomenai was classified as "Solokha I/mushroom-rimmed amphora" and included in the mid-4th century BCE group. ${ }^{66}$

57 Benndorf and Niemann 1889.

58 Lagerlöf 2000, 77-78, fig. 35.

59 Ruggendorfer 2016, 71-72.

60 Borchhardt and Stanzl 1990, 71-84.

61 Mendel 1914, 44-45, no. 286.

62 Ridgway 1999, 155.

63 Sakarya 2016, 185, no. 45, pl. XIII.

64 Monachov 1999, 162, fig. 3.1.

65 Monakhov et al. 2017, 112, Kn. 6.

66 Özbay 2019, 91, no. 19, dwg. 19. 
A rim-neck fragment found among the examples from Patara, classified as "South Aegean mushroom-rimmed amphora", is similar to the Knidos find in terms of form. This amphora from Patara has been dated to the late 4th century BCE. ${ }^{67}$ Similar pieces from the Athenian Agora are dated to the late 4 th century BCE. ${ }^{68}$ Considering the close similarity in terms of form with the examples mentioned above, the mushroom-rimmed amphora fragment from Knidos could be dated to the second half of the 4th century BCE.

The main production places of amphorae with mushroom-shaped rims still remain a topic of dispute. It has been reported that this form was produced at numerous centers in the South Aegean region including Samos, Rhodes, Knidos, Kos, Halikarnassos, Peparethos, Klazomenai and Phokaia. ${ }^{69}$ Currently it does not seem possible to clearly verify where this mushroomrimmed amphora fragment from Knidos was produced. However, considering the form characteristics of this rim-neck fragment, it is clear that similar amphorae were produced in workshops across the southern Aegean. Based on the clay composition, this amphora fragment from Knidos was probably produced somewhere close to the Southern Aegean Region.

The composition of the Centaur-Lapith battle on the gem stamp on the handle of the mushroom-rimmed amphora from Knidos is significant in terms of the tradition of stamping amphorae. Stamps are not common in centers that produced mushroom-rimmed amphorae. Mushroom-rimmed amphorae produced in Knidos feature ligature and monogram stamps. However, there are no other known examples of stamps depicting a mythological subject on mushroom-rimmed amphorae. In this context, this amphora stamp, evaluated here in terms of shape, production place, and iconography, is a unique artefact for portraying a mythological story.

It should be questioned why the diversely used Centauromachy iconography has found a place on an amphora stamp. In ancient literature, and especially during the Hellenistic Period, Centaurs were depicted as creatures with an incorrigible desire for wine. Maybe the workshop that applied this amphora stamp preferred to use the scene semantically to demonstrate the quality and strength of their wine.

\section{Catalogue}

\begin{tabular}{|c|c|}
\hline Inventory No. & : KD73.HNBCE t 16 P 2470 \\
\hline Year Found & $: 1973$ \\
\hline Find Spot & : North Harbour Byzantine Church E - Trench 16 \\
\hline Clay Colour & : 7.5 YR $6 / 3$ pale red \\
\hline Slip Colour & : 7.5 YR 6/1 reddish grey \\
\hline Inclusions & $\begin{array}{l}\text { : A high concentration of lime, moderate amounts of sand, a small amount } \\
\text { of chamotte and a few stone particles and quartz }\end{array}$ \\
\hline Stamp Shape & : Oval \\
\hline Stamp Dimension & $: 1.9 \times 1.3 \mathrm{~cm}$ \\
\hline Stamp Description & : Battle of Centaur and Lapith. \\
\hline Shape Description & $\begin{array}{l}\text { A mushroom-shaped/out turned rim with a triangular cross-section, a } \\
\text { cylindrical neck and an oval-sectioned handle which rises slightly before } \\
\text { bending down towards the neck with a narrow curve. }\end{array}$ \\
\hline
\end{tabular}

67 Dündar 2017, 467, no. MrA.9, pl. 17.

68 Lawall 2004b, 451, pl. 451, nos. 19-20.

69 Özbay 2019, 83. 


\section{Bibliography}

\section{Ancient Sources}

Apollodoros, Bib. Frazer, J. G. 1921. Bibliotheka. The Library. New York/London: William Heinemann.

Homeros, Odys. Erhat, A., and A. Kadir. trans. 2008. Homeros, Odysseia. Istanbul: Can Yayınları.

Homeros, Il. Butler, S. 1889. Homeros, Illias. The Illiad of Homer. London: Hanson \& Co. At the Ballantyne Press.

\section{Modern Works}

Alkaç, E. 2019. "Knidos Kazılarında Bulunan Amphora Mühürleri Üzerine İlk Değerlendirmeler.” Arkhaia Anatolika 2:84-101.

Barringer, J.M. 2009. "A New Approach to the Hephaisteion: Heroic Models in the Athenian Agora." In Structure, Image, Ornament: Architectural Sculpture in the Greek World, Proceedings of an International Conference beld at the American School of Classical Studies, 27-28 November 2004, edited by P. Schultz and R. von den Hoff, 121-32. Oxford/Oakville, CT: Oxbow Books.

Baur, P.V.C. 1912. The Centaurs in Ancient Art, the Archaic Period. Berlin: Karl Curtius.

Beazley, J.D. 1963. Attic Red-Figure Vase-Painters. Oxford: Clarendon Press.

Benndorf, O., and G. Niemann. 1889. Das Heroon von Gjölbaschi-Trysa. Jahrbuch der kunsthistorischen Sammlungen des allerhöchsten Kaiserhauses 9. Vienna: Adolf Holzhausen.

Borchhardt, J., and G. Stanzl. 1990. "Ein hellenistischer Bau des Herrscherkultes: Das Ptolemaion von Lymra." In Götter, Heroen, Herrscher in Lykien, edited by J. Borchhardt, R. Jacobek, and A. Dinstl, 79-84. Vienna: A. Schroll.

Cankardeş-Şenol, G. 2001. "Metropolis'den Hellenistik Döneme Ait Bir Grup Amphora Mühürü.” Olba 4:101-14.

Cankardeş-Şenol, G. 2006. Klasik ve Hellenistik Dönem'de Mühürlü Amphora Üreten Merkezler ve Mübürleme Sistemleri. Istanbul: Ege Yayınlar1.

Cankardeş-Şenol, G. 2010. "Nikandros Group: Matrix Studies on the Amphora Stamps of the Group." Olba 18:125-39.

Cankardeş-Şenol, G. 2015. "Early Cnidian Amphora Exports to Alexandria, Egypt." In Recent Studies on the Archaeology of Anatolia, edited by E. Lafl1 and S. Patac1, 169-92. BAR-IS 2750. Oxford: Archaeopress. Publishers of British Archaeological Reports.

Childs, W.A.P. 1978. The City-Reliefs of Lycia. Princeton Monographs in Art and Archaeology 42. Princeton: Princeton University Press.

Coşkun, G., and F. Çevirici-Coşkun. 2017. "Seyitömer Höyük M.Ö. 5. ve 4. Yüzyıl Ticari Amphoraları.” Ege Üniversitesi Edebiyat Fakültesi Arkeoloji Dergisi 22:229-43.

Delivorrias, A. 1969. "Poseidon Tempel auf Kap Sounion Neue Fragmente der Friesdekoration." $A M$ 84:127-42.

Desborough, V.R.d'A., R.V. Nicholls, and M.R. Popham. 1970. "A Euboean Centaur.” BSA 65:21-30.

Dinsmoor, W.B. 1975. The Architecture of Ancient Greece: An Account of its Historic Development. 3rd ed. New York: W.W. Norton.

Doğer, E. 1986. "Premières remarques sur les amphores de Clazomènes." In Recherces sur les Amphores Grecques, edited by J.-Y. Empereur and Y. Garlan, 461-71, BCH Suppl. 13. Athens/Paris: École Française d'Athènes/de Boccard.

Doğer, E., and A.K. Şenol. 1996. "Rhodos Peraiası'nda İki Yeni Amphora Atölyesi.” Ege Üniversitesi Edebiyat Fakültesi Arkeoloji Dergisi 4:59-73. 
Doksanaltı, E.M., İ. Karaoğlan, and D.O. Tozluca. 2018. Knidos. Denizlerin Buluştuğu Kent. Ankara: Bilgin Kültür ve Sanat Yayınları.

Doksanaltı, E.M., İ. Karaoğlan, E. Aslan, İ.M. Mimiroğlu, L.U. Erdoğan, D.O. Tozluca, and G. Ünver. 2019. "Knidos Kazı ve Araştırmaları: 2017.” Kazı Sonuçları Toplantısı 40.2:45-64.

Doulgéri-Intzessiloglou, A., and Y. Garlan. 1990. "Vin et amphores de Péparéthos et d'Ikos." $B C H$ 114.1:361-89.

Dündar, E. 2017. Transport Jars and Stamped Amphoras from Patara, 7th to 1st Centuries BC. The Maritime Trade of a Harbor City in Lycia. Patara 4.3. Istanbul: Ege Yayınlar1.

Empereur, J.-Y., and M. Picon. 1986. "Des ateliers d'amphores à Paros et à Naxos." BCH 110.1:495-511.

Felten, F., and K. Hoffelner. 1987. "Die Relieffriese des Poseidontempels in Sunion.” AM 102:169-84.

Hasdağlı, İ. 2012. "The Assessment of the 4th Century B.C. Finds from Three Wells Uncovered at Clazomenae HBT (Hamdi Balaban Tarlasi) Sector.” Olba 20:119-64.

Hölscher, T. 2000. "Feindwelten, Glückswelten. Perser, Kentauren und Amazonen." In Gegenwelten: zu den Kulturen Griechenlands und Roms in der Antike, edited by T. Hölscher, 287-320. München/ Leipzig: Saur.

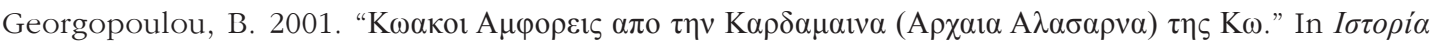

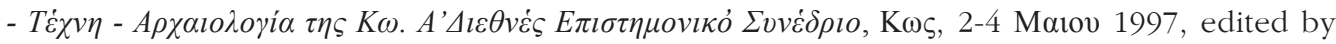
G. Kokkorou-Aleura, A.A. Laimou, and E. Semantone-Mpournia, 107-14. Athens: Panepistemio Athenon.

Grace, V., and M. Savvatianou-Petropoulakou. 1970. "Les timbres amphoriques Grecs." In L'ilot de la Maison des Comédiens, edited by P. Bruneau and T. Homelle, 277-382. Délos 27. Paris: De Boccard.

Grace, V. 1971. "Samian Amphoras." Hesperia 40.3:52-95.

Jefremow, N. 2013. "Ceramic Stamps of the Late Classical - The Early Hellenistic Knidos. 'Protoknidian' Stamps and the Stamps with the 'Ship's Bow'." Questions of Epigraphy 7.1:405-51.

Jenkins, I. 2006. Greek Architecture and Its Sculpture. Boston: Harvard University Press.

Jenkins, I. 2007. The Parthenon Sculptures in the British Museum. London: British Museum Press.

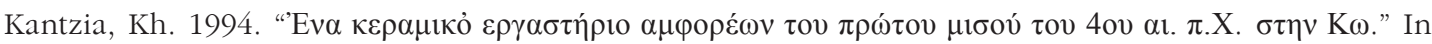

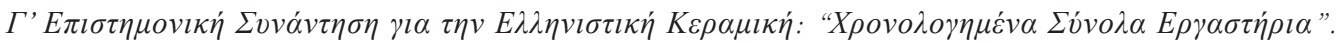

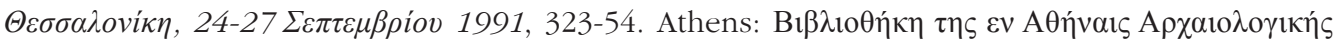

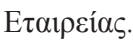

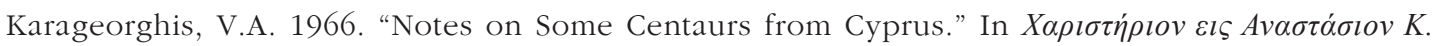

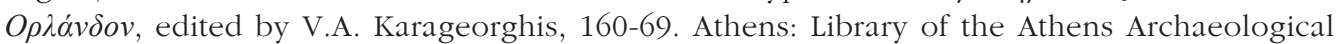
Society.

Lagerlöf, M.R. 2000. The Sculptures of the Parthenon: Aesthetics and Interpretation. New Haven/London: Yale University Press.

Lawall, M.L. 1995. "Transport Amphoras and Trademarks: Imports to Athens and Economic Diversity in the Fifth Century B.C.” Ph.D. diss., Michigan University.

Lawall, M.L. 2004a. "Archaeological Context and Aegean Amphora Chronologies: A Case Study of Hellenistic Ephesos." In Transport Amphorae and Trade in the Eastern Mediterranean. Acts of the International Colloquium at the Danish Institute at Athens. September 26-29, 2002, edited by J. Eiring and J. Lund, 171-88. Monographs of the Danish Institute at Athens 5. Aarhus: Aarhus University Press.

Lawall, M.L. 2004b. "Amphoras without Stamps: Chronologies and Typologies from the Athenian Agora."

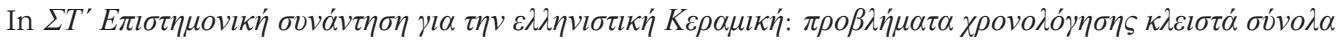

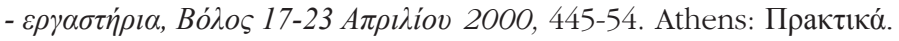


Mendel, G. 1914. Musées impériaux ottomans: Catalogue des sculptures grecques, romaines et byzantines, tome 3. Constantinople: Musée Impérial.

Monachov, S.J. 1999. "Towards a Typology of Knidian Amphoras of the 4th-2nd c. BC. / K tipologii knidskikh amfor IV-II vv. do. n.e." In The Bosporan Phenomenon: Greek Culture on the Periphery of the Ancient World/Bosporski fenomen: Grecheskaia kultura na periferii antichnogo mira: materialy mezhdunarodnoi nauchnoi konferentsii, edited by M.J. Vakhtina, 161-72. St. Petersburg.

Monakhov, S.Y., E.V. Kuznetsova, and N.B. Churekova. 2017. Amphorae of the 5th-2nd c. BC. from the Collection of the State Museum-Preserve "Tauric Chersonese". Catalogue. Saratov: Novÿi proekt Press.

Morgan, C.H. 1962. "The Sculptures of Hephaisteion II. The Friezes.” Hesperia 31.3:221-35.

Papuci-Wladyka, E. 1997. "A Research Report on Hellenistic Pottery: Cos Amphoras." Studies in Ancient Art and Civilization 8:47-54.

Patay-Horváth, A., 2015. "Introduction. Adopting a New Approach to the Temple and its Sculptural Decoration." In New Approaches to the Temple of Zeus at Olympia, Proceedings of the First Olympia-Seminar, 8th-10th May 2014, edited by A. Patay-Horváth, 1-14. London: Cambridge Scholars Publishing.

Padgett, J.M., W.A.P. Childs, and D. Tsiafakis. 2003. The Centaur's Smile: The Human Animal in Early Greek Art. Princeton: Princeton University Art Museum.

Podlecki, A.J. 1971. "Cimon, Skyros, and 'Theseus' Bones.” JHS 91:141-43.

Ridgway, B.S. 1999. Prayers in Stone: Greek Architectural Sculpture (c. 600-100 B.C.E.). Sather Classical Lectures. Vol. 63. California: University of California Press.

Roscher, H.W. 1890-1894. Ausführliches Lexikon der griechischen und römischen Mythologie. Band 2, Abteilung 1, lache-Kyzikos. Leipzig: Druck und Verlag von B.G. Teubner.

Ruggendorfer, P. 2016. Das Mausoleum von Belevi. Archäologische Untersuchungen zu Chronologie, Ausstattung und Stiftung. Ephesos 6.2. Vienna: Verlag der Österreichischen Akademie der Wissenschaften.

Özbay, F. 2019. "Klazomenai FGT (Feride Gül Tarlas1) Sektöründen Ele Geçen İthal Ticari Amphoralar." Dumlupinar Üniversitesi Sosyal Bilimler Dergisi 59:74-94.

Sakarya, İ. 2016. "Trade Relations of Ancient Burgaz from Archaic to Mid of 4th Centuries: The Amphorae Evidence within the Domestic Contexts.” Ph.D. diss., Ortadoğu Teknik University.

Schiffler, B. 1976. Die Typologie des Kentauren in der antiken Kunst vom 10. bis zum Ende des 4. Jahrbunderts v. Chr. Archäologische Studien 4. Frankfurt: Peter Lang.

Şenol, A.K. 1995. "Erken Knidos Amphoralarında (İ.Ö. III. Yüzyıl) Monogram Mühürleri.” Master's thesis, Ege University.

Şenol, A.K., and E. Aşkın. 2007. "Amphoralar Işı̆̆ında Kentin Ticari İlişkileri.” In Dağlık Kilikia'da Bir Antik Kent Kazısınm Sonuçlar, Nagidos. Results of an Excavation in an Ancient City in Rough Cilicia, edited by S. Durugönül, 241-97. Adalya Suppl. 6. Istanbul: AKMED.

Şenol, A.K., 2009. "AETAM'da Bulunan Amphoraların Tipolojisi." In AETAM'da (Arslan Eyce Taşucu Amphora Müzesi) Bulunan Ticari Amphoralar ve Akdeniz'de Ticaretin Izleri, edited by A.K. Şenol, 100-319. Silifke: Taşeli Matbaacılık.

Şenol, A.K. 2015a. "Smyrna Kazılarında 2011-2007 Yilları Arasında Bulunan Ticari Amphoralar.” In Smyrna/İmir Kazı ve Araştırmalar 1. Çalıstay Bildirileri, edited by A. Ersoy and G. Şakar, 24356. Antik Smyrna Kazısı Yayın Çalısmaları 3. Istanbul: Ege Yayınları.

Senol, A.K. 2015b. "New Evidences on the Amphora Production in the Rhodian Peraea during the Early Hellenistic Period." In Recent Studies on the Archaeology of Anatolia, edited by E. Lafli and S. Patac1, 193-201. BAR-IS 2750. Oxford: Archaeopress. 
Tarbell, F.B. 1920. "Centauromachy and Amazonomachy in Greek Art: The Reasons for Their Popularity." AJA 24.3:226-31.

Tuna, N., J.-Y. Empereur, M. Picon, and E. Doğer. 1987. "Rapport préliminaire de la prospection archéologique Turco-Française des ateliers d'amphores de Reşadiye-Kiliseyanı, sur la Péninsule de Datça." Anatolia Antiqua 1:47-52.

Tuna, N. 1990. "Datça Yarımadasında Hellenistik Dönem Amphora Üretim Merkezleri." In X. Türk Tarih Kongresi, I. Cilt, 22-26 Eylül 1986, 347-71. Ankara: Türk Tarih Kurumu.

Zeest, I.B. 1960. Keramicheskaia tara Bospora. Materialy i issledovaniia po arkheologii SSSR 83. Moskova: Izd-vo Akademii nauk SSSR.

Makale Geliş / Received : 30.12.2019

Makale Kabul / Accepted : 06.04.2020 


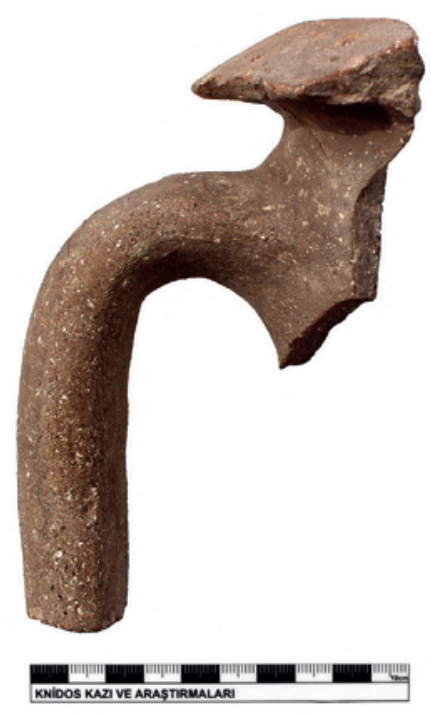

FIG. 1 Mushroom-rimmed amphora fragment from Knidos.

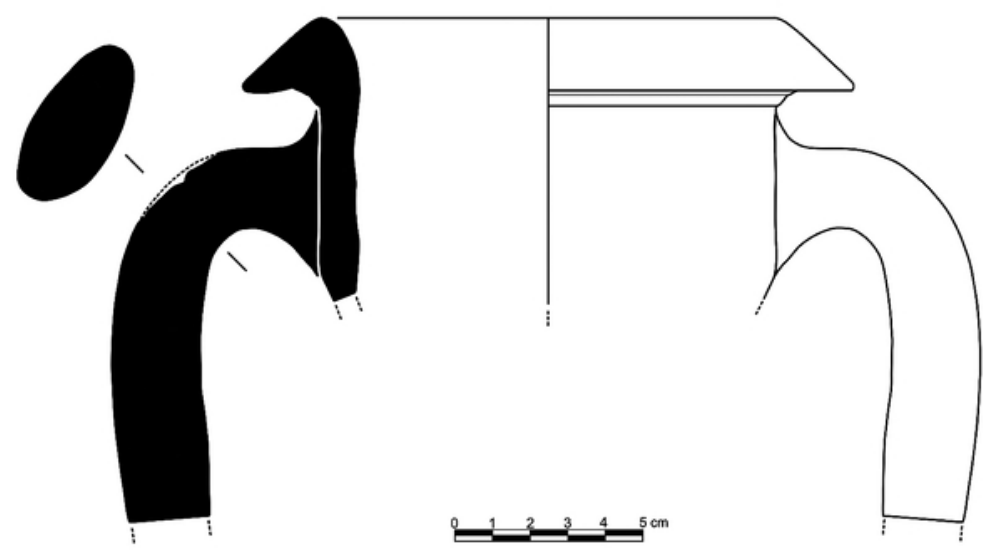

FIG. 2 Drawing of mushroom-rimmed amphora fragment from Knidos.

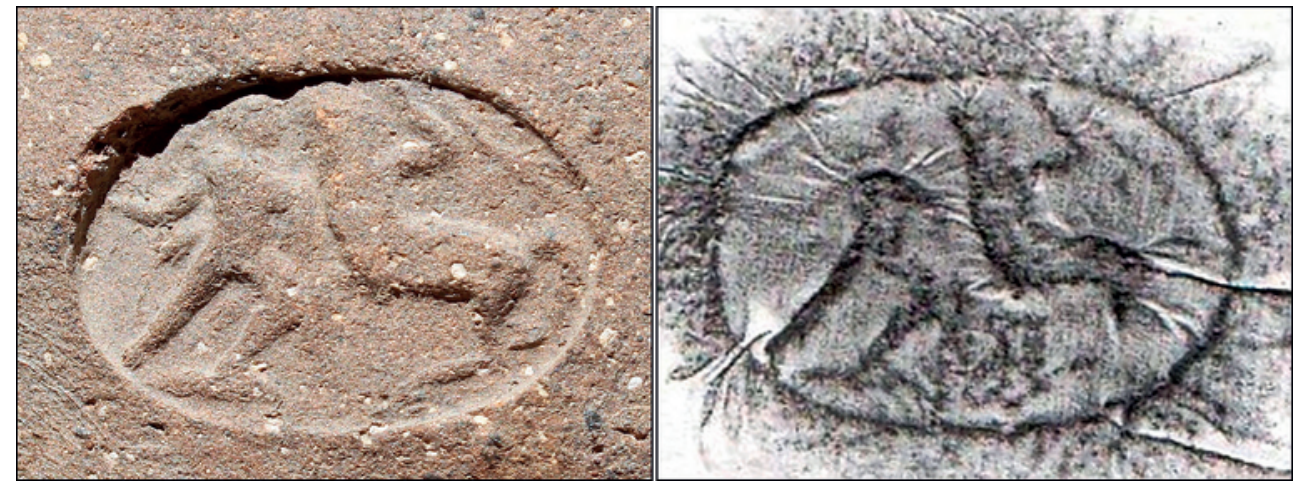

FIG. 3 Gem stamp with depiction of the Centaur-Lapith battle on the handle. 